\title{
Management Skills and Performance of State-Owned Enterprises in Cameroon
}

\author{
Fonkam Mongwa Nkam \\ Department of Banking and Finance, Faculty of Social and Management Sciences, University of Buea, Buea, Cameroon
}

Email address:

fonkamsson@gmail.com

\section{To cite this article:}

Fonkam Mongwa Nkam. Management Skills and Performance of State-Owned Enterprises in Cameroon. Journal of Business and Economic Development. Vol. 6, No. 2, 2021, pp. 115-124. doi: 10.11648/j.jbed.20210602.17

Received: May 19, 2021; Accepted: June 1, 2021; Published: June 9, 2021

\begin{abstract}
Like in most Sub-Sahara Africa, State-Owned Enterprises (SOEs) in Cameroon have a complex, overlapping and unclear management model that impacts its performance. The purpose of this study is to evaluate the effect of managerial skills on the performance of SOEs in Cameroon. Survey research design was used to collect data from top and middle level managers. The sample was drawn form 10 of the 14 SOEs that are wholly or partially owned by the state. By using purposive sampling, likert scale data was collected using questionnaires. The explanatory variables were managerial skills (conceptual, technical, interpersonal, budgeting and planning, cost control and ability to secure capital) and the outcome variable was performance. Managers were asked to rate their abilities in possessing some skills. Their opinions were also asked about the performance of the enterprises they manage. By analyzing the data using Ordinal logistic regression it was found that conceptual, technical, interpersonal, budgeting and planning skills had significant and positive effect on performance while cost control and skills to secure capital had insignificant and positive effects on performance. To improve performance, the study recommended that the government should organize skill-based training seminars for the three management levels (supervisors, middle and top managers).
\end{abstract}

Keywords: Managerial Skill, State-Owned Enterprises, Performance, Ordered Logit

\section{Introduction}

After World War II, governments created State-Owned Enterprises (SOEs) to correct market deficits, capital shortfalls, promote economic recovery and reduce unemployment [1]. To have a firm grip on their economies, governments were present in the transportation, mining, aviation, shipping, trading, banking, communication, construction, manufacturing sectors. As important partners in development, SOEs controlled swaths of GDP in the world.

While SOEs in developed countries have good performance levels, only few in developing countries struggle to meet private sector performance levels. Those that copy well established best practices in the private sector are closing the gap in terms of competition and performance. Most SOEs in Africa are plagued with corporate governance issues, lack of management skills, political interferences, nepotism and transparence in operations [2]. Most of them do not meet their profit targets and pose serious financial pressure on state resources.
After colonization, SOEs in Africa were created to partner the private sector in infrastructural building and economic development [3]. They were part of the industrialization strategies in Sub-Sahara Africa [4]. However, their localization was more political than commercial. The poor performance in Sub-Sahara Africa was due to multiple and conflicting objectives and incompetent management. Many Leaders in this region often rewarded loyalists, supporters and party faithfuls with undeserved management positions. As a consequence most the enterprises underperformed and were liquidated [5].

In order streamline, deregulate and reduce the burden on state budgets, many countries implemented the International Monetary Fund (IMF) and World Bank's Structural Adjustment Programs (SAP) in the 1980's and 90's [6]. These were in the form of privatization, commercialization, public-private partnerships, build-operate and transfer. However, persistent leadership and management challenges in some countries made these reforms to fail and the performance of SOEs remained a dilemma [7]. 


\subsection{Evolution of State-Owned Enterprises in Cameroon}

Ahmadou Ahidjo, Cameroon's first president created many public enterprises after independence. By mid-1980, there were 219 SOEs that employed more than 100,000 Cameroonians [8]. His objective was to increase the role of the state in the economy. They were government affiliates in redistribute national resources in terms of employment, provision of basic necessities, power, prestige and served as compensation to political allies [9]. They partnered with private investors in accelerating economic development.

After privatization, there are there are 128 SOEs in Cameroon as at January 2020. Thus, Cameroon is the second African country with many SOE's. More than $70 \%$ are administrative entities for public services while less than $30 \%$ are SOEs [10]. The state has monopolies in sectors that require intensive capital investments such as electricity and road infrastructure. These SOES also compete with the private sector for market share in sectors such metal products, cement, glass and insurance. According to a survey of 27 subsectors carried out by World Bank [10], the state controls at least one firm in 20 subsectors in Cameroon compared to an average of eight sectors in the five countries surveyed. The wholly owned and majority-owned enterprises have a commercial orientation and a financial autonomy. In terms of employment SOEs collectively employed about 45,000 workers in 2017. This represents about one-sixth of total employment by the public sector [11].

\subsection{Performance of State-Owned Enterprises in Cameroon}

Despite their contribution to the economy, these enterprises have witnessed deteriorating profitability and financial autonomy. Their revenues are decreasing; operating costs and indebtedness are increasing. There is over dependence on state subsidies. There are 40 commercial SOE's had a combined turnover of 1.4 trillion (US\$2.95 billion); representing about 11 percent of its GDP in 2013. During this same period, their combined net loss was 13.7 billion (US\$27.8 million). From the 2017 finance law, 8 out of 15 wholly owned SME's were regularly unprofitable while 4 made little profit [11]. The unprofitable ones had an operating profit ratio of $-48 \%$ and a ratio of salaries to revenue of $100 \%$ (and to operating profit of $38 \%$ ) in 2016 (National Institute of Statistics [12]. Only 4 of the 15 that existed in 2014 could generate sufficient revenue to cover their operating costs, depreciation and financial charges. With this poor performance, most SME's in Cameroon contribute very little to state revenue but have rather become a burden to the already strained state budget [13]. Revenue to the state in the form of dividends has been decreasing. It decreased from FCFA 1.3 billion (about US\$17.1 million) in 2013 to FCFA1.1 million (about US\$15.9 million) in 2016 [12].

Most of the enterprises have accumulated contingent liabilities such as arrears, cross debts and outstanding claims from the government and other stakeholders [11]. Their total gross debts increased from $11.7 \%$ of GDP in 2014 to $12.5 \%$ of GDP in 2016. Two-thirds of these debts are supplier and financial debts (securitized debt, banks and other soft loans). Their debts to the state represented 2\% of GDP in 2016 while claims on the state decreased to $0.3 \%$ of GDP; down from $1.4 \%$ of GDP in 2014. As at 2017, their average debt-to asset ratio was $66 \%$ with an average default ratio (equity/share capital) of -4 [11].

In 2017, total claims less taxes owed were $65 \%$ of its turnover (NIS, 2017). Coupled with outstanding claims, fiscal debts are very high; increasing from CFAF175 billion (about US\$318 million) in 2013 to CFA175 billion (about US $\$ 332$ million) in 2016. This represented about $7 \%$ of total government revenue and $0.4 \%$ of GDP $[12,11]$.

With accumulated and continuing losses these enterprises depend on net fiscal transfers in the form of subsidies for survival. In 1994, state subsidies to SMEs stood at FCFA150 billion. This represented about $40 \%$ of total national debts. However, these subsidies increased from 0.4 percent of GDP in 2009 to 0.9 percent in 2012 [13]. In 2015 FCFA 57.4 billion subsidies to SOE' came from the state budget while FCFA19.4 billion was from operating and investment subsidies of operating ministries [14].

The SOEs management model in Cameroon is complex, overlapping and lacks clarity. Most SOEs have negative profitability trend and rising debt levels. This has created serious debates among academicians, labor unions, international organizations and policy makers. Apart from enterprise and country specific characteristics, majority of these enterprises face numerous problems such as lack of proper accountability, poor management, mismanagement, bribery and corruption, wastages, pilferages, corruption, incompetence of directors and employees, inefficiencies, political interferences and poor governance issues. Most of these problems are often blamed for their poor financial performance.

Some SOEs in Cameroon do not even produce yearly financial statements as noted by the audit bench of the Supreme Court. This institution has in numerous occasions indicated that only one in five SOEs actually produce yearly financial reports despite the presence of the Ministry of Finance through its "Commission Technique de Rehabilitation (CTR) on the boards of all SOEs. The mission of the CTR is to observe and ensure that SME's produce annual reports. SOEs that were not privatized signed performance based management contracts with the state. This was never implemented and today their performance targets are poor and lack clarity.

Coupled with this, the management of SMEs is always mixed with politics. Management vacancies are rarely advertised. The board chairman and general Manager are always co-opted without considering their management skill levels. Most management positions are filled on political party lines and not competence. Thus, they do not have the necessary skills and strategies to improve their performance. These among other factors above have resulted in disturbing and disappointing financial performances.

Due to this poor performance, the government has taken some measures such as replacing the chief executive of non- 
performing enterprises and convicting those with corrupt practices. Even rehabilitation agreements with the IMF and World Bank have not made the matter better. Despite these measures, revenues of majority SOEs continue to be low, operating costs continue increase, accumulated debts remain unpaid and government subsidies continue to increase. This has continued to keep international partners, the state of Cameroon, policy makers and academicians worried.

The performance of SOEs in Cameroon is not well researched. However, some researchers studied them from the perspectives of privatization, deregulation and value creation [9, 15-18]. Few studies compared the performance of SOEs with those of private enterprises [19]. However, the IMF and World Bank have written policy papers on their performance. This study is different from previous academic studies in that it seeks to study their performance from the managerial perspective.

Therefore, this paper is motivated by the inadequacy of current literature and policy measures to improve on the performance of SOEs in Cameroon. The research question is; do managerial skills in SOEs in Cameroon affect their performance? In order to answer this question the specific objective is to evaluate the effect of conceptual, technical, interpersonal, planning, budgeting, cost control and ability to secure capital skills on the performance of SOEs in Cameroon. The working hypothesis is that management skills do not seem to affect the performance of SOEs in Cameroon.

\section{Literature Review}

Due to inadequate research on management skills and performance of SOEs, the empirical literature in this study is built on concepts and theories.

\subsection{State-Owned Enterprises}

SOEs are industrial and commercial firms controlled by the government with most of their revenue from the sale of goods and services [20]. They are corporate bodies created by the legislature with defined powers and functions and independently having a clear cut jurisdiction over a specific type of commercial activity [21]. In this study SOEs mean government owned companies created to fulfill specific functions and operate within the governing legislature to promote effective and efficient service delivery.

\subsection{Management Skills}

Different schools of thought have provided various meanings of management skills. They are a set of behaviors that can lead to effective job and performance [22]. They can also be viewed as a manager's ability to transform information and knowledge in to practice [23]. In this paper, we define it as necessary attributes developed through formal education and training in order to efficiently and effective perform some tasks and create value in organizations.

Katz [23] and Mintzberg [24], identified conceptual, technical, analytical, interpersonal, and budgeting skills as essential for managers to positively change their organizations. Many schools of thoughts believe that age, gender, experience, education level and expertise could lead to effective management [22]. Education and experience help a manager to acquire the necessary conceptual, technical and interpersonal and budgeting skills that will make them perform their jobs and improve performance [25]. Managers with conceptual skills easily visualize the various segments of the whole business. It's easy for them to identify the strengths and weaknesses, prepare for unforeseen events, improve their problem solving abilities, make good decisions, plan and organize the organizational resources in order to improve performance. As job specific skills, a manager with technical skills should be able to perform specialized activities in the organization. Similarly, a manager with interpersonal skills should be able to understand, lead, alter and control the behavior of people and groups in the organization he managers. A manager with budgeting and planning skills is always proactive in managing the company's money. The manager is conscious of every financial allocation he makes such that expenses do not surpass revenue [25].

\subsection{Enterprise Performance}

There exist many definitions of enterprise performance. The point of convergence is that they consist of various inputs and measures. Enterprise performance consists of accounting and market based measures [26]. However, Murphy [27], recommended the use of accounting measures such as financial metrics and financial performance ratios in describing a company's performance. However, Katz [23], recommended observable measures such as revenue and profits from audited financial statements. Return on Equity (ROE) has been the predominant measure of financial performance [28]. However, Ngwenya and Khumalo [29], recommended Return on Assets (ROA) as a good measure of financial performance because ROE can be manipulated to improve the ratio. Since profitability is the proxy used to measure financial performance in this study, it is necessary to understand it. Profitability is the outcome of a number of policies and decisions that can be in the form of Earnings Before Interest and Taxed or Earnings After Tax (net profit).

\subsection{Contingency Theory}

This study centers around the contingency approach of management since managerial skills are measured based on the ability to develop strategies, allocate resources, communicate, measure and manage performance and resolve problems in order to improve performance. The theory postulates that there is no single way or approach in managing. In making decisions that affect the organization, a manager must use all aspects of the current situation in order to make good decisions. Hence the contingency approach management is an important management approach as it helps managers to use their conceptual skills and experiences 
to develop strategies that will improve al performance.

\subsection{Agency Theory}

Developed by Jensen and Meckling [30], this theory explains the contractual relations between the principal who engages an agent to make certain decisions on his behalf by delegating some powers. In terms of this study, the government hires managers in SOEs to create value in terms of performances and dividends. In order to meet government's aspirations, managers of these enterprises are supposed to use their skill sets. Because of asymmetric information and conflict of interest, most managers in SOEs often act on their own behalf by practicing unorthodox business practices. At the threshold of bankruptcy, these managers always believe that the government will use all measures to rescue the enterprise. For this reason most of the public sector managers always adopt a lackadaisical method in managing resources [31]. Managers in SOEs find it difficult to identify the principals and align their interest; thus making their tasks complex.

\subsection{The Performance of State-Owned Enterprises}

There are some empirical studies on the performance of SOEs. Luqmani and Quraeshi [32], found inefficient operations, poor service quality and increase in subsidies from the state as major causes of poor performance. In another study, Ayee [5], found that lack of attention in changing management, the inability to move from the old system of personal management to human resource management, frequent leader turnover, lack of political commitment and lack of the necessary management skills are causes of poor performance. [1] Ackah et al. [1], found poor corruption, management inefficiency and lack of sustainable leadership skills to be causes of poor performance. Walumbwa et al. [7], attributed the poor performance of SOEs to haphazard implementation of sustainable governance reforms. On the performance of SOEs in developing countries Mahadeo, and Soobaroyen [33], found lack of knowledge on the operations of SOEs as the main cause of poor performance. However, Simpson [6], Florio [34], Obara and Ogoun [35], found corporate governance as the main cause of poor performance; while Batley et al. [36], identified institutional crises as the main for poor performance.

\subsection{Managerial Skills and Firm Performance}

Managerial skills have been recognized as important constructs of firm performance [37-39]. Helfat and Peteraf [37], further opined that firms with a blend of strong managerial skills are capable of minimizing costs and incentivizing financial growth. Similarly, Ahmad and Ahmad [40], underscored the fact that modern firms which ignore the multiple dimensions of managerial skills underperform. However, Helfat and Peteraf [37], found out that firms that which are reluctant in recognizing managerial skills as a driver of performance turn to have a low performance and high failure rate. In terms of SME performance, Ahmad and Ahmad [41], found a positive effect of managerial skills on SME performance in Pakistan. In Nigeria Aliyu [42], found significant impact of planning, organizing, leadership and controlling skills on SME performance.

The resource-Based View of the firm by Wernerfelt [43], equally recognizes managerial skills as one of the corner stones to better a firm's performance and improved competitive advantage in terms of cost reduction. According to this view, managerial skills are important resources that can drive growth and a firm's sustainability. Mehralian et al. [44], supported this argument and added that managerial skills lead to better utilization of a firm's resources and good performance.

\section{Research Methodology}

This study is descriptive in nature and uses a survey research design. The study population was top and middle managers drawn from 10 of the 15 SOEs that are either wholly or majority owned by the government. Because of socio-political crises in some parts of the country it was difficult to travel. The 10 SOEs had 132 top and middle management staff. We used purposive sampling since the study population was not large enough and the participants had to meet the criteria of being a top or middle manager. There are three levels of management namely supervisors, middle management and top management [45]. Our respondents were top and middle managers because they use skills in directing the vision and performance of the SOEs they manage.

A total of 132 structured questionnaires were administered to the 132 top and middle managers of the 10 selected SOEs. Due to the busy work schedules of some managers, the questionnaires were administered during 5 months. Commitment letters were signed with the respondents in order to encourage them to participate. An undertaking was signed to keep their identities and that of the enterprises they manage private and to give them the results and conclusions of the study.

Out of the 132 respondents, 102 finally responded giving a response rate of $77.2 \%$. The questions were closed ended and of likert scale type. The questionnaire had three sections. Section one was about the age, gender, marital status, education level and work experience of respondents. In section two the managers were asked to do a self-assessment of their abilities in possessing and using some skills. The skills were conceptual, analytical and forecasting, interpersonal, planning and budgeting, cost control and skill to secure capital. The likert scale question was in the form 0 , 1, 2, 3, 4 and 5 for No ability, very low ability, low ability, high ability and very high ability respectively. The level of ability indicated the level of the managerial skill. That is, low ability indicated that the manager did not have the skill while the level of high ability indicated that manager had and is used the skill in the enterprise.

In section three, managers were asked to indicate if the 
performance (net profits) of the enterprises they managed was low, moderate or high using a three point likert scale of 1 , 2 and 3 for low, moderate and high respectively. Low level meant that the company was not profitable, moderate level meant that it was breaking-even and high level meant that the enterprise had a was making profits. The variables were validated using experts in the field and previous literature. To ensure that our results were appropriate and consistent, the instruments were operationally defined.

\subsection{Model Specification}

The Ordered logistic regression model (ologit) with maximum likelihood was the appropriate model instead of the Ordinary Least Squares (OLS) to evaluate the effect of managerial skills on the performance of SOEs in Cameroon. This was because the dependent variable (performance) was ordinal. Using OLS in this instance would have made the results spurious. Ologit uses maximum likelihood methods to find the best regression coefficients to predict values of the logittransformed probability that the outcome variable falls into one category instead of the other. According to Long and Freese [46], the logit model is based on cumulative probabilities of the dependent variable which is assumes to be a linear function of the covariates with constant coefficients across respond categories. The values of each category had a meaningful sequential order where each value was higher than its predecessor. According to Liao [47], and Greene [48], the functional form of the ordered logistic model is specified as:

$$
Y^{*}=\sum_{k=1}^{k} \beta k X k+\varepsilon
$$

Where;

$\mathrm{Y}^{*}=$ is unobserved and underlines the tendency of observed phenomenon.

$\varepsilon$ is the error term which follows a symmetric distribution.

In this study, the relationship between financial performance of SOEs (outcome variable) and managerial skills (explanatory variables) were assumed to logistic. The ordinal logistic model specific to this study is written as;

$$
\operatorname{logit}\left(p e r *_{i}^{*}\right)=p_{i} / 1-p_{i}=?+\beta_{1} C_{i}+\beta_{2} T_{i}+\beta_{3} I_{i}+\beta_{4} B_{i}+\beta_{5} C_{i}+\beta_{6} S_{i}+\beta_{7} E_{i}+\beta_{8} E d_{i}+\varepsilon_{i}
$$

Where;

$\operatorname{perf}_{i}=$ is the level of profitability according to respondent $\mathrm{i}$

$\mathrm{i}=$ individual respondents $(\mathrm{i}=1,2,3, \ldots 102)$

$\mu=$ overall mean

$\beta_{\mathrm{i}}=$ logit regression coefficients for each explanatory variable

$\varepsilon_{\mathrm{i}}=$ randon errors assumed to be constant

$\mathrm{C}_{\mathrm{i}}=$ conceptual skills of respondent $\mathrm{i}$

$\mathrm{T}_{\mathrm{i}}=$ Technical skills of respondent $\mathrm{i}$

$\mathrm{I}_{\mathrm{i}}=$ Interpersonal skills of respondent $\mathrm{i}$

$\mathrm{B}_{\mathrm{i}}=$ Budgeting and planning skills of respondent $\mathrm{i}$

$\mathrm{Cc}_{\mathrm{i}}=$ cost control skills of respondent $\mathrm{i}$

$\mathrm{Sc}_{\mathrm{i}}=$ skills to secure capital of respondent $\mathrm{i}$

$\mathrm{E}_{\mathrm{i}}=$ working experience of respondent $\mathrm{i}$
$\mathrm{Ed}_{\mathrm{i}}=$ education level of respondent $\mathrm{i}$

\subsection{Variables and Measurements}

Net profit was used as a proxy of performance as recommended by Katz [23]. Since SOEs are large business entities; the study also used conceptual, technical, interpersonal, planning and budgeting skills as explanatory variables in accordance with Mintzberg [24]. However, this study considered cost control and skills to secure capital as peculiar to SOEs in developing countries. This is because these enterprises have rising cost structures, rely on government subsidies for funding and barely use external financing sources when cash-strapped.

Dependent variable: It is financial performance and proxied using net profit according to Katz [23]. It was measured on an ordinal scale.

Independent Variables (measured on ordinal scale)

Conceptual Skills are abilities to analyze and perceive events, anticipate changes, recognize opportunities and threats and distingue between cause and effect.

Technical skills are job specific knowledge and techniques.

Interpersonal Skills are abilities to lead and motivate workers, work with people and resolve work conflicts.

Budgeting and planning skills are abilities to forecast revenues and expenses

Cost control skills are abilities to allocate and controlling operating and financial costs.

Skills to secure capital are the abilities to use other sources of finance instead of relying on subsidies.

\subsection{Validity Tests}

After coding the responses, a number of pre-test were conducted to ensure that no assumption of ologit regression was violated. For internal validity and reliability the Cronbach's Alpha coefficient was used. The association and between the model variables was verified using the correlation matrix and multi-collinearity verified with the Variance Inflation Factor (VIF). For potential model identification issues the Anderson Canon LM statistic and Sargan Hansen statistics were used. After assurance that none of these assumptions was violated, STATA 13 was used to analyze the data. The results of descriptive statistics and inferential statistics are presented below.

\section{Descriptive and Inferential Statistics}

The descriptive and inferential results are presented below.

\subsection{Descriptive Statistics}

Table 1. Gender of Respondents.

\begin{tabular}{lll}
\hline Gender & Frequency & percentage \\
\hline Males & 81 & 79.5 \\
Females & 21 & 20.5 \\
Total & 102 & 100 \\
\hline
\end{tabular}

Source: Survey Data, 2021. 
From table 1 above, $79.5 \%$ of the managers were male while 20.5 were female.

Table 2. Marital Status of Respondents.

\begin{tabular}{lll}
\hline Marital Status & Frequency & Percent \\
\hline Single & 9 & 9.8 \\
Married & 93 & 91.1 \\
Total & 102 & 100 \\
\hline
\end{tabular}

Source: Survey Data, 2021.

As shown in table 2 above, $91.1 \%$ of the managers are married while $9.8 \%$ are single.

Table 3. Education Level of Respondents.

\begin{tabular}{lll}
\hline Education level & Frequency & Percent \\
\hline Bachelor Degree & 53 & 52 \\
Master Degree & 43 & 42.1 \\
Doctorate Degree & 6 & 5.9 \\
Total & 102 & 100 \\
\hline
\end{tabular}

Source: Survey Data, 2021.

From table 3 above, $52 \%$ of the mangers have bachelor degrees, while $42.1 \%$ have master degrees. Only 5.9\% have Doctorate degrees. This is understandable given that most of the managers have attained the positions through appointments.

From table 4 above, most of the managers (30.4\%) have worked up to 15 years while $4.9 \%$ have worked for more than 30 years. However, up to $17 \%$ with only 5 years of experience are already serving as managers.

Table 4. Working Experience of Respondents.

\begin{tabular}{lll}
\hline & Frequency & Percent \\
\hline 0-5 years & 17 & 17 \\
6-10 years & 24 & 24 \\
11-15 years & 31 & 30.6 \\
16-20 years & 17 & 16.7 \\
21-30 years & 8 & 8.8 \\
30 years and above & 5 & 4.9 \\
Total & 102 & 100 \\
\hline
\end{tabular}

Source: Survey Data, 2021.

Table 5. The Age Ranges of Respondents.

\begin{tabular}{lll}
\hline Age Range & Frequency & Percent \\
\hline 30-40 years & 18 & 17.8 \\
41 to 50 years & 33 & 33.7 \\
51 to 60 years & 45 & 44.6 \\
61-70 years & 6 & 5.9 \\
Above 71 years & 0 & 0 \\
Total & 102 & 100 \\
\hline
\end{tabular}

Source: Survey Data, 2021.

Table 5 above shows that most of the managers (44.6\%) of age while $5.9 \%$ who are between 61 and 70 years of age are supposed to have retired since the retirement age in Cameroon is 60 years.

Table 6. Descriptive Statistics.

\begin{tabular}{|c|c|c|c|c|c|}
\hline Variable & Obs & Mean & Std. Dev. & Min & Max \\
\hline Net profit & 102 & 1.921569 & 0.65531 & 1 & 3 \\
\hline experience & 102 & 3.637255 & 0.74181 & 1 & 5 \\
\hline conceptual skills & 102 & 4.127451 & 1.021274 & 1 & 5 \\
\hline analytical skills & 102 & 3.666667 & 1.102053 & 1 & 5 \\
\hline interpersonal skills & 102 & 4.27451 & 0.93509 & 1 & 5 \\
\hline planning and Budgeting Skills & 102 & 4.147059 & 1.24596 & 1 & 5 \\
\hline cost control skills & 102 & 3.598039 & 1.036558 & 1 & 5 \\
\hline skills to secure capital & 102 & 3.623487 & 1.100012 & 1 & 5 \\
\hline
\end{tabular}

Source: Computed from STATA 12.

From table 6 above, the standard deviation of net profit, experience, sex and interpersonal skills are low meaning low variability of these variables from the mean. Variables with high standard deviations are conceptual skills, analytical skills, planning and budgeting skills and skills to secure capital; indicating high variability from the mean.

Table 7. Cronbach Alpha Coefficients of Explanatory Variables.

\begin{tabular}{lll}
\hline Scale & No of Items & Cronbach Alpha Coefficient \\
\hline Experience & 102 & 0.621 \\
Education Level & 102 & 0.657 \\
Conceptual skills & 102 & 0.642 \\
Technical Skills & 102 & 0.693 \\
Interpersonal Skills & 102 & 0.648 \\
Budgeting and Planning skills & 102 & 0.672 \\
Cost control skills & 102 & 0.691 \\
skills to secure capital skills & 102 & 0.654 \\
\hline
\end{tabular}

Source: Survey Data, 2021. 
Table 8. Correlation Matrix between Management Skills and Performance.

\begin{tabular}{|c|c|c|c|c|c|c|c|c|c|}
\hline & NP & CON & ANA & INT & PBU & $\mathrm{COC}$ & SCC & EXP & EDU \\
\hline Net Profit (NP) & 1 & & & & & & & & \\
\hline conceptual (CON) & 0.1085 & 1 & & & & & & & \\
\hline analytical (ANA) & 0.1026 & 0.1202 & 1 & & & & & & \\
\hline interpersonal (INT) & 0.0169 & 0.2637 & -0.237 & 1 & & & & & \\
\hline planning and Budgeting (PBU) & 0.1016 & 0.2419 & 0.0721 & -0.12 & 1 & & & & \\
\hline cost control (COC) & 0.0618 & 0.1705 & 0.0029 & 0.023 & 0.2609 & 1 & & & \\
\hline skills to secure capital (SSC) & 0.0638 & -0.0161 & 0.1086 & -0.0443 & 0.0221 & -0.0034 & 1 & & \\
\hline experience (EXP) & 0.0036 & 0.0821 & 0.0565 & 0.3546 & 0.3368 & 0.1047 & 0.2792 & 1 & \\
\hline education level (EDU) & 0.0887 & -0.0639 & 0.0153 & -0.1565 & 0.0771 & -0.0888 & -0.0042 & 0.106 & 1 \\
\hline
\end{tabular}

Source: Authors' calculations in Stata 13.

\subsection{Inferential Statistics}

To ensure consistency of the ologit regression coefficients, the reliability of the model instruments using Cronbach Alpha is presented as table 7 , correlation as table 8 , muticollinearity as table 9 , model identification as table 10 and ologit results as table 11 .

From table 7, the alpha coefficients are within the accepted level of 0.70 ; meaning that the model instruments are valid and reliable.

Table 8 above shows the direction and strength of the relationship between the study variables. There is positive relationships exist between all the variables. This indicates that an increase in will lead to an increase in net profits is associated with an increase in these variables. It is also observed that a negative relationship exist between interpersonal skills and analytical skills, budgeting and planning skills, skills to secure capital and experience. This is the same situation with skills to secure capital with conceptual skills, interpersonal skills and cost control skills.

Table 9. Multi-collinearity Results using VIF.

\begin{tabular}{lll}
\hline Variable & VIF & 1/VIF \\
\hline planning skills & 1.31 & 0.766031 \\
interpersonal Skills & 1.3 & 0.768357 \\
conceptual skills & 1.2 & 0.832211 \\
Cost control skills & 1.1 & 0.907018 \\
analytical skills & 1.07 & 0.93274 \\
skills to secure capital & 1.03 & 0.94727 \\
Education level & 1.04 & 0.957945 \\
experience & 1.29 & 0.775295 \\
Mean VIF & 1.003 & \\
\hline
\end{tabular}

Source: Computed from STATA 13.
From table 9 above, the magnitudes of the correlation coefficients are less that the recommended value of 0.8 . This is confirmed by the mean VIF of 1.003 . The mean VIF is lower than the recommended VIF 10 implying that there is no multi-collinearlity.

Table 10. Anderson Canon Correlation LM Statistic and Sargan Hansen Model Identification Results.

\begin{tabular}{lll}
\hline & Net Profit \\
\cline { 2 - 3 } & Test Statistic & P-Value \\
\hline Anderson Canon. Corr LM statistic & 17.736 & $0.0003^{*}$ \\
Sargan Statistic & 0.198 & 0.9016 \\
\hline
\end{tabular}

*, significant at $1 \%$.

The results on table 10 above show that the p-value of the Anderson Canon Correlation LM statistic is significant at $1 \%$ level of significant. Thus we reject the null hypothesis that the model is under-identified. Similar, the p-value of the Sargan Statistic is insignificant. Thus we fail to reject the null hypothesis that the over-riding restrictions are valid and conclude that they are valid. Therefore, the ologit model is correctly identified and the estimation instruments are all valid.

The likelihood ratio of the model is high and significant at $1 \%$ level of significance. Thus, we reject the hypothesis that the coefficients of the intercepts equal zero. It also signifies a high explanatory power of the combined association of managerial skills on the performance of SOEs in Cameroon. The pseudo $\mathrm{R}^{2}$ of 0.2181 implies that $21.8 \%$ of the variations in SOE performance in Cameroon can be explained by the explanatory variables in the model while $78.2 \%$ is explained by other factors. This implies that it is good enough for policy implications.

Table 11. Ordinal Logistic Parameter Estimates.

\begin{tabular}{|c|c|c|c|c|c|c|}
\hline Profitability & Coef. & Std. Err. & $\overline{\mathbf{z}}$ & $\mathbf{P}>\mathbf{Z}$ & {$[95 \%$ Conf. } & Interval] \\
\hline Age & 0.044 & 0.060 & -0.710 & 0.467 & -0.041 & 0.537 \\
\hline Gender & 0.022 & 0.218 & 0.090 & 0.891 & -0.031 & 0.737 \\
\hline Experience & 0.382 & 0.355 & -1.080 & 0.282 & -1.078 & 0.314 \\
\hline Education Level & 0.353 & 0.200 & 1.860 & 0.116 & -0.082 & 0.614 \\
\hline Marital Status & 0.191 & 0.215 & 0.870 & 0.282 & -1.078 & 0.314 \\
\hline conceptual skills & 0.484 & 0.228 & 2.130 & $0.033 * *$ & 0.038 & 0.931 \\
\hline Analytical and forecasting skills & -0.336 & 0.194 & -1.730 & $0.083 * * *$ & -0.715 & 0.044 \\
\hline Planning and budgeting skills & 0.471 & 0.228 & 2.070 & $0.039 * *$ & 0.025 & 0.918 \\
\hline Cost control skills & 0.307 & 0.207 & 1.480 & 0.138 & -0.098 & 0.713 \\
\hline Skills to secure capital & 0.378 & 0.234 & 1.610 & 0.107 & -0.081 & 0.837 \\
\hline
\end{tabular}




\begin{tabular}{|c|c|c|c|c|c|c|}
\hline Profitability & Coef. & Std. Err. & $\mathbf{z}$ & $\mathbf{P}>\mathbf{Z}$ & [95\% Conf. & Interval] \\
\hline /cut1 & -1.422 & 2.534 & & & -6.389 & 3.545 \\
\hline /cut2 & 2.294 & 2.352 & & & -2.316 & 6.903 \\
\hline /cut3 & 4.607 & 2.406 & & & -0.108 & 9.323 \\
\hline No of Observations & 102 & & & & & \\
\hline LR Chi2 (8) & 45.49 & & & & & \\
\hline Prob $>\mathrm{Chi}^{2}$ & 0.000 & & & & & \\
\hline Pseudo $\mathrm{R}^{2}$ & 0.2181 & & & & & \\
\hline log Likelihood & -81.526 & & & & & \\
\hline
\end{tabular}

$*, * *, * * *$ are $1 \%, 5 \%$ and $10 \%$ significant levels respectively.

Source: ologit output from survey data, 2021.

\section{Discussion of Findings}

The ologit regression results in table 11 shows that conceptual, interpersonal, planning and budgeting skills have a positive and significant effect on performance while analytical and forecasting skills have a negative and significant effect on the performance of SOEs in Cameroon. These variables are significant all significant at all significant levels $(1 \%, 5 \%$ and $10 \%)$. Although the coefficients of cost control and skills to secure are insignificant, they have positive effects on performance. Other model variables such as age, experience, gender, education level and marital status equally have positive but insignificant effects on the performance of SOEs in Cameroon.

In terms of significant skills, holding other variables constant an increase in conceptual skills will lead to an increase in performance. Specifically, a one unit increase in conceptual skills will result to a $48.4 \%$ increase in in SOE performance in Cameroon. This result is in according with the studies of Mintzberg [24], Katz [23], the contingency and agency theories of management. With this skill managers in SOEs can see the entire organization as one, benchmark their practices with peers in the private sector and anticipate events in the enterprises.

Holding other variables constant, an increase in interpersonal skills will result to an increase in performance. Specifically, a one unit increase in interpersonal skills will lead to a $99.9 \%$ increase in the performance of SOEs in Cameroon. This result is consistent with the studies of Mintzberg [24], Katz [23], Ayee [5] and Ackah et al. [1]. It is also consistent with the contingency and agency theories as managers can use this skill to develop strategies that can meet the principal's aspirations. From this finding it can be posited that a manager with this skill can use it to change the actions and mentality of stakeholders and improve performance.

Table 11 also reveals that a decrease in a decrease in technical skills will lead to a decrease in performance holding other variables constant. That is, a unit change in analytical and forecasting skills will result to a $33.6 \%$ decrease in performance of SOEs in Cameroon. This result is in according with the study of Mintzberg [24], and Katz [23]. In support their findings, managers with this skill can lead by example since they are perceived to be more specialized and experienced in the organization.

The coefficient of budgeting and planning skills also mean that an increase in this skill will cause an increase in performance. Holding other variables constant, a unit change planning and budgeting skills will cause a $47.1 \%$ increase in SOE performance in Cameroon respectively. This result is according to the recommendations of Mintzberg [24], and Katz [23]. From the findings and empirical studies, this study can add that budgeting and planning in public enterprises in Cameroon is not participatory. Managers with this skill are proactive and conscious of every financial allocation they make.

\section{Conclusion}

The objective of this study is to evaluate the effects of managerial skills on the performance of state-owned Enterprises in Cameroon. From the findings, conceptual, technical, interpersonal, budgeting and planning skills have significant effects on the financial performance of the enterprises they manage. Therefore, these skills are important in improving the already poor financial situation of the enterprises. Though not significant, cost control and skills to secure capital have positive effects on performance. This might be due to the characteristics of SOEs in Cameroon such as perceptions of managers, poor control and overreliance on subsidies.

Based on the findings and conclusion this study recommends that in order to improve the performance of SOEs in Cameroon the government should organize skillbased training seminars for staff in the three management levels (supervisors, middle and top managers). The government should also implement and adopt leadership skills in the management of state enterprises. This should be by translating the skills of each manager in to decision making strategy process.

\section{References}

[1] Ackah, C., Adjasi, C., \& Turkson, F. (2014). Scoping study on the evolution of industry in Ghana (No. 2014/075). WIDER Working Paper. Al-Madhoun, M., \& Analoui, F. (2002). Developing managerial skills in Palestine. Education Training.

[2] Amankwah-Amoah, J. (2014). Organizational expansion to underserved markets: Insights from African firms. Thunderbird International Business Review, 56 (4), 317-330.

[3] Bin-Yahya, F. (2012). Divesting state owned enterprises. International Review of Business Research Papers, 8 (4), 195 206. 
[4] Opoku, D. K. (2010). From a 'success' story to a highly indebted poor country: Ghana and neoliberal reforms. Journal of Contemporary African Studies, 28 (2), 155-175.

[5] Ayee, J. R. (2013). The developmental state experiment in Africa: The experiences of Ghana and South Africa. The Round Table, 102 (3), 259-280.

[6] Simpson, S. N. Y. (2014). Boards and governance of stateowned enterprises. Corporate Governance.

[7] Walumbwa, F. O., Avolio, B. J., \& Aryee, S. (2011). Leadership and management research in Africa: A synthesis and suggestions for future research.

[8] Konings, P. (2011). The politics of neoliberal reforms in Africa: State and civil society in Cameroon. African Books Collective.

[9] Lengue, C. T. (2011). Privatizations in Africa; the Cameroon Example. The Harmatan Editions.

[10] World Bank (2018). Fostering Skills in Cameroon Inclusive Workforce Development, Competitiveness, and Growth. http://documents.worldbank.org/curated/en/501141543353309 $471 /$.

[11] IMF, (2018). Cameroon, IMF Country Report No. 20/48. Fifth Review Under the Extended Credit Facility Arrangement. https://www.imf.org/en/Publications/CR/Issues/2020/02/14.

[12] NIS, (2020). Economic and financial data base of 2017, 5th Edition.

[13] IMF, (2015). Cameroon selected issues ", IMF Country Report No 15/332, December 2015, 23 pages. https://www.imf.org/en/Publications/CR/Issues/2016/12/31.

[14] Fouda, S. M. (2016). Press release », cabinet meeting of February 25, 2016, 3 pages.

[15] Bekolo, C. (1995). The re-launching of public enterprises in Cameroon: A liberalization approach.

[16] Touna, M. \& Tamba, I. (1996). Crises and de-regularization in the public and para-public sectors: Economic and political crises of de-regulation in Cameroon. Harmattan, page 135-193.

[17] Nzomo, J. T., \& Nzongang, J. (2007). The process of privatisation of public and Para-public enterprises in Cameroon: An assessment. Journal of sustainable development in Africa, 9 (4), 229-246.

[18] Onana, A. A., \& Tamanjong, R. L. (2018). Do State Owned Enterprises in Cameroon Create Value?. Revue de Recherches en Economie et en Management Africain, 6 (6), 145-157.

[19] Tchankam, J. P. (2000). Comparative performances of public and private enterprises: An empirical study in a country in the development process. Recherches en Sciences de Gestion, (5), 157-182.

[20] Nhema, A. G. (2015). Privatisation of public enterprises in developing countries: An overview. International Journal of Humanities and Social Science, 5 (9), 247-256.

[21] Nwoye, M. I. (2011). Privatization of public Enterprises in Nigeria: The views and counterviews. Journal for Political theory and research on Globalization, Development and Gender Issues, 2 (4), 234-251.

[22] Mujtaba, B. G., Javed, M., \& Nguyen, L. D. (2013).
Management skills of Pakistanis: a comparison of technical, human and conceptual differences. Advances in management and applied economics, 3 (3), 129.

[23] Katz, R. L. (2009). Skills of an effective administrator. Harvard Business Review Press.

[24] Mintzberg, H. (1975). The manager's job: Folklore and fact.

[25] Tajaddini, R., Mujtaba, B. G., \& Bandenezhad, M. (2010). Management skills of Iranians: A comparison of technical, human and conceptual differences based on gender, age and longevity in management ranks. Labour and management in development, 10.

[26] Attaway, M. C. (2000). A study of the relationship between company performance and CEO compensation. American business review, 18 (1), 77.

[27] Murphy, K. J. (1999). Executve compensaton. In O. Ashenfelter \& D. Card (Eds.), Handbook of labor economics (Vol. 3, pp. 2486-2557). San Diego, USA: NorthHolland.

[28] Bussin, M., \& Modau, M. F. (2015). The relationship between chief executive officer remuneration and financial performance in South Africa between 2006 and 2012. SA Journal of Human Resource Management, 13 (1), 1-18.

[29] Ngwenya, S., \& Khumalo, M. (2012). CEO compensation and performance of state owned enterprises in South Africa.

[30] Jensen, M. C., \& Meckling, W. H. (1976). Theory of the firm: Managerial behavior, agency costs and ownership structure. Journal of financial economics, 3 (4), 305-360.

[31] Mulili, B. M., \& Wong, P. (2011). Corporate governance practices in developing countries: The case for Kenya. International journal of business administration, 2 (1), 14.

[32] Luqmani, M., \& Quraeshi, Z. (2011). Privatizing state-owned enterprises: a model for developing countries. International Journal of Commerce and Management.

[33] Mahadeo, J. D., \& Soobaroyen, T. (2012). Corporate governance implementation in an African emerging economy: The case of state-owned entities. In Accounting in Africa. Emerald Group Publishing Limited.

[34] Florio, M. (2013). Rethinking on public enterprise: Editorial introduction and some personal remarks on the research agenda. International Review of Applied Economics, 27 (2), 135-149.

[35] Obara, C., \& Ogoun, S. (2014). Fiscal transparency, accountability, and corporate collapse: A post-mortem analysis of failure of state-owned enterprises (SOEs) in Nigeria. Research Journal of Finance and Accounting, 5, 183190 .

[36] Batley, R., McCourt, W., \& Mcloughlin, C. (2012). The politics and governance of public services in developing countries.

[37] Helfat, C. E., \& Peteraf, M. A. (2015). Managerial cognitive capabilities and the microfoundations of dynamic capabilities. Strategic management journal, 36 (6), 831-850.

[38] Shaikh, K. H., Ahmedani, M. M., Syed, A. A. S. G., \& Panhwar, M. M. A. P. (2017). A Managerial perspective on the issues of the barriers to the development of SME Sector of Pakistan. NICE, Research Journal of Social Science, 7 (14), $1-10$. 
[39] Wijaya, E. R., \& Irianto, D. (2018, March). Analysis influence of managerial competence, Technical competence, And strategic competence on firm performance in electrical engineering company in bandung. In IOP Conference Series: Materials Science and Engineering (Vol. 319, No. 1, p. 012081). IOP Publishing.

[40] Ahmad, I., \& Ahmad, S. (2019). The Mediation Effect of Strategic Planning on The Relationship Between Business Skills and Firm's Performance. Opcion, 35 (24), pp. 746-778.

[41] AHMAD, I., \& AHMAD, S. B. (2021). Effect of Managerial Skills on the Performance of Small-and Medium-Sized Enterprises: A Case Study in Pakistan. The Journal of Asian Finance, Economics and Business, 8 (4), 161-170.

[42] Aliyu, M. D. Y. O. I. (2015). Impact of managerial skills on small scale businesses performance and growth in Nigeria.

[43] Wernerfelt, B. (1984). A resource-based view of the firm. Strategic management journal, 5 (2), 171-180.
[44] Mehralian, G., Peikanpour, M., Rangchian, M., \& Aghakhani, H. (2020). Managerial skills and performance in small businesses: the mediating role of organizational climate. Journal of Asia Business Studies.

[45] Kaifi, B. A., \& Mujtaba, B. G. (2010). A Study of Management Skills with Indian Respondents: Comparing their Technical, Human and Conceptual Scores Based on Gender. Journal of Applied Business \& Economics, 11 (2), 223-236.

[46] Long, J. S., \& Freese, J. (2006). Regression models for categorical dependent variables using Stata (Vol. 7). Stata press.

[47] Liao, T. F. (1994). Interpreting probability models: Logit, probit, and other generalized linear models (No. 101). Sage.

[48] Greene, W. H. (2000). Econometric analysis 4th edition. International edition, New Jersey: Prentice Hall, 201-215. 